\title{
A COMPARISON OF THE MORBIDITY PATTERNS OF THE ARMY WITH THOSE IN CIVILIAN COMMUNITIES
}

\author{
R. R. SOWDEN, B.Sc., Ph.D. \\ Ministry of Defence, States 23, Stanmore
}

\begin{abstract}
SUMMARY. A comparison is presented of inpatient sickness in the Army with certificated sick leave in the non-industrial Civil Service and claims for sickness benefit under the National Insurance Scheme. It is shown that whilst the frequency of such sickness in the Army is much lower than in the two civilian communities, the length of incapacity is appreciably longer. Thus sickness in the Army is associated with relatively greater impact in terms of time lost.
\end{abstract}

\section{Introduction}

The patterns of morbidity in the Army have been the subject of much study and comment over the years, both in regularly published quarterly and annual reports and in special investigations. Consideration has been given to changes over time and to com, parisons between groups of individuals and areas of operation. This has resulted in a detailed knowledge of the patterns to be expected under particular circumstances. However, relatively little has been said as to how the experience in the Army compares with that of other populations, particularly of a civilian community.

The extent to which such comparisons can be made depends upon the availability of data and the degree to which such data describe comparable areas of sickness experience. The validity of such an exercise will depend upon the characteristics of the populations under study, upon occupational and general environmental factors and upon the way in and even extent to which sickness is treated in different areas. If only because of its selective nature, differences between the Army and a civilian community are to be expected, so that any comparisons of a general nature might only serve to put the various groups concerned into some sort of perspective. In this paper, summaries of published data for two civilian populations are presented, together with details for the Army. These seem to represent the best bases possible with currently available information.

\section{Sources and definitions}

The data quoted relate to sick leave in 1967 amongst civil servants (Civil Service Department 1971) and to claims for benefit under the National Insurance Scheme between June 1968 and May 1969 (Whitehead 1971). Detailed definitions are given in the references. For the Civil Service, the figures are in respect of male, non-industrial civil servants under 45 years of age, excluding Post Office and Diplomatic Service staff, for whom sick leave is certificated or uncertificated according to whether or not it is supported by medical evidence. The latter is allowed for absence of up to five days and for a total of ten days in any twelve months. As regards the general community, the figures relate to males under 45 years of age insured under the National Insurance Acts, so that the principal exclusions are members of Her Majesty's Forces, mariners whilst at sea, most non-industrial civil servants and post office workers. Benefit is not payäble for the first three days of sickness unless there is a total of twelve days or more in any period of thirteen weeks. 
On the basis of these definitions and the situation in the Army, it is felt that the best available comparisons are between inpatient admissions to all medical units in the Army, certificated sick leave for the Civil Service and all claims for sickness benefit in the general community. The vast majority of minor sickness should then be excluded, whilst the inclusion for the Army of admissions to Medical Reception Stations should take care of most civilian sickness covered under these definitions treated at home.

\section{Results}

Table 1 provides details for the Army of admissions to medical units in the United

Table I

Inpatient admissions of British Army males in the United Kingdom in 1967

\begin{tabular}{|c|c|c|c|c|c|c|c|}
\hline & \multicolumn{7}{|c|}{ Age groups. Admission rates per 1000} \\
\hline Age (years) & $0-19$ & $20-24$ & $25-29$ & $30-34$ & $35-39$ & $40-44$ & All \\
\hline Age distribution (percentage) & 26.4 & 32.2 & 17.6 & 10.0 & 8.8 & 5.0 & 100.0 \\
\hline $\begin{array}{l}\text { Influenza, bronchitis, colds etc. } \\
\text { Other respiratory diseases } \\
\text { Musculoskeletal } \\
\text { Injuries } \\
\text { Digestive disorders } \\
\text { Mental disorders } \\
\text { Circulatory disorders } \\
\text { Malignant neoplasms } \\
\text { Other causes }\end{array}$ & $\begin{array}{r}98 \\
10 \\
11 \\
84 \\
35 \\
7 \\
3 \\
97\end{array}$ & $\begin{array}{r}25 \\
9 \\
11 \\
57 \\
31 \\
7 \\
4 \\
\frac{67}{67}\end{array}$ & $\begin{array}{r}13 \\
7 \\
10 \\
35 \\
27 \\
4 \\
5 \\
\frac{5}{47}\end{array}$ & $\begin{array}{r}9 \\
5 \\
9 \\
23 \\
27 \\
4 \\
7 \\
42\end{array}$ & $\begin{array}{r}5 \\
5 \\
7 \\
11 \\
27 \\
3 \\
7 \\
2 \\
41\end{array}$ & $\begin{array}{r}7 \\
6 \\
11 \\
12 \\
28 \\
4 \\
9 \\
2 \\
39\end{array}$ & $\begin{array}{r}38 \\
8 \\
10 \\
51 \\
30 \\
6 \\
5 \\
1 \\
65\end{array}$ \\
\hline All causes & 345 & 210 & 148 & 126 & 107 & 117 & 213 \\
\hline All causes excluding influenza & 338 & 208 & 147 & 125 & 106 & 117 & 210 \\
\hline $\begin{array}{l}\text { Average duration of stay, all } \\
\text { causes (days) }\end{array}$ & 11.5 & 17.2 & 18.9 & 17.4 & 18.5 & 18.9 & 15.1 \\
\hline $\begin{array}{l}\text { Non-effective rate per } 1000 \text {, } \\
\text { all causes }\end{array}$ & 10.9 & 9.9 & 7.7 & 6.0 & 5.4 & 6.1 & 9.5 \\
\hline
\end{tabular}

Source: F Med 14 Records

Kingdom during 1967 as reported on F Med 14 1ecords. It shows the age distribution of the population at risk, admission rates for broad cause categories, average durations of stay and non-effective rates. Table 2 deals with certificated sick leave terminating in 1967 for the Civil Service, and gives the age distribution of the population at risk, the frequencies of sick leave spells and their average length, together with non-effectiveness. Where sick leave spans a weekend the two days are included. For the general population, no breakdown by cause is available and influenza is excluded. Table 3 gives the composition of the population at risk, and the frequency and average length of spells of incapacity beginning between June 1968 and May 1969. In addition to age-specific quantities and all-ages figures, Tables 2 and 3 give values standardised to the age distribution of the Army. Although the time periods concerned are not identical, it is considered that this will not affect the results to any extent.

It is interesting to note the marked similarity between the overall rates for the general community and the Civil Service, although the former do not include influenza. 
Table II

Certificated sick leave of Non-industrial male civil servants in 1967

\begin{tabular}{|c|c|c|c|c|c|c|c|c|}
\hline \multirow[b]{2}{*}{ Age (years) } & \multicolumn{7}{|c|}{$\begin{array}{c}\text { Age groups } \\
\text { Rates of periods terminating per } 1000\end{array}$} & \multirow{3}{*}{$\begin{array}{l}\text { Standardised } \\
\text { to Army age } \\
\text { distribution }\end{array}$} \\
\hline & $0-19$ & $20-24$ & $25-29$ & $30-34$ & $35-39$ & $40-44$ & All & \\
\hline Age distribution (percentage) & 9.0 & 25.9 & 13.5 & 14.0 & 16.4 & 21.2 & 100.0 & \\
\hline $\begin{array}{l}\text { Influenza, bronchitis, colds etc. } \\
\text { Other respiratory diseases } \\
\text { Musculoskeletal } \\
\text { Injuries } \\
\text { Digestive disorders } \\
\text { Mental disorders } \\
\text { Circulatory disorders } \\
\text { Malignant neoplasms } \\
\text { Other causes }\end{array}$ & $\begin{array}{r}209 \\
27 \\
15 \\
53 \\
37 \\
\frac{6}{116}\end{array}$ & $\begin{array}{r}202 \\
27 \\
16 \\
46 \\
36 \\
4 \\
1 \\
117\end{array}$ & $\begin{array}{r}165 \\
25 \\
10 \\
28 \\
38 \\
3 \\
3 \\
120\end{array}$ & $\begin{array}{r}181 \\
29 \\
25 \\
54 \\
35 \\
3 \\
4 \\
131\end{array}$ & $\begin{array}{r}147 \\
25 \\
24 \\
31 \\
35 \\
7 \\
10 \\
1 \\
125\end{array}$ & $\mid \begin{array}{r}131 \\
17 \\
29 \\
25 \\
22 \\
9 \\
8 \\
1 \\
111\end{array}$ & $\begin{array}{r}171 \\
25 \\
20 \\
38 \\
33 \\
5 \\
5 \\
119\end{array}$ & $\begin{array}{r}187 \\
26 \\
17 \\
43 \\
36 \\
3 \\
4 \\
119\end{array}$ \\
\hline All causes & 461 & 445 & 392 & 474 & 405 & 353 & 417 & 435 \\
\hline $\begin{array}{l}\text { Average length of period, } \\
\text { all causes (days) }\end{array}$ & 8.2 & 10.0 & 10.5 & 11.7 & 13.3 & 14.3 & 11.5 & 10.2 \\
\hline $\begin{array}{l}\text { Non-effective rate per } 1000 \text {, } \\
\text { all causes }\end{array}$ & 10.4 & 12.2 & 11.3 & 15.2 & 14.8 & 13.8 & 13.1 & 12.2 \\
\hline
\end{tabular}

Source: Civil Service Department (1971)

Table III

Claims for National Insurance Sickness Benefit. Males June 1968 -May 1969 All causes excluding influenza

\begin{tabular}{l|c|c|c|c|c|c|c|c}
\hline & \multicolumn{9}{c}{ Age groups } & $\begin{array}{l}\text { Standardised } \\
\text { to Army age } \\
\text { distribution }\end{array}$ \\
\hline Age (years) & $0-19$ & $20-24$ & $24-29$ & $30-34$ & $35-39$ & $40-44$ & All \\
\hline Age distribution (percentage) & 11.5 & 19.8 & 17.4 & 16.9 & 16.9 & 17.5 & 100.0 & \\
\hline Inception rate per 1000 & 450 & 431 & 413 & 433 & 403 & 390 & 418 & 429 \\
\hline
\end{tabular}

Source: Whitehead (1971)

Not unexpectedly, the Army shows much lower frequencies both overall, for which the value is only 50 per cent of the Civil Service figure, and for most individual causes. The effect of excluding influenza admissions in the Army is mainly in the lowest age-groups. The corresponding overall rate is about 50 per cent of the age-standardised inception rate for the general population. In terms of specific causes, differences in rates between the Army and Civil Service are particularly marked for respiratory diseases, whilst the Army shows a higher rate for mental disorders and injuries. There is far greater variation in rates with age in the Army, with a general decline towards the higher ages. Particularly noticeable is the relatively high rate amongst those under 20 years of age, a feature not reflected generally in the other populations.

Average duration of stay for the Army overall is 50 per cent higher than average length of sickness spell for the Civil Service. In the Army it is relatively constant in all 
age-groups apart from those aged 19 and under, whereas length of spell in the Civil Service increases uniformly with age. The effect of the appreciably higher averages in the Army is to produce a corresponding non-effective rate only 23 per cent lower than that for the Civil Service. It should also be borne in mind that duration of stay for the Army does not include any subsequent sick leave. Whilst actual figures for this are not available, that portion of sick leave granted or recommended by the medical units and recorded on F Med 14 records amounts to an average of 2.5 days. Adding this to the duration of stay produces a non-effective rate for the Army of about 11 per 1000 . Whilst this would certainly include sickness which in the Army would not result in inpatient admission, the extreme is to consider all sick leave in the Civil Service by adding in uncertificated leave. This results in a standardised non-effective rate of about 16 per 1000 . On balance it would seem that whilst incidences of non-trivial sickness in the Army are much lower than in the two civilian groups considered, the relative impact of this sickness in terms of time lost is greater.

\section{REFERENCES}

Civil Service Department Management Studies (1971). No. 1: Sickness Absence in the Civil Service. H.M.S.O. London.

Whitehead, F. E. (1971). Trends in Certificated Sickness Absence. Social Trends No. 2. H.M.S.O. London.

\section{ACADEMIC ACHIEVEMENTS}

F.F.A.R.C.S.

M.R.C.Psych.

D.Obst.R.C.O.G.

D.C.H.

D.P.H.

D.T.M.\&H.
Lieutenant-Colonel J. McEwan, M.B., ch.B., R.A.m.C.

MAJOR J. R. BIRD, M.B., B.S., M.R.C.S., L.R.C.P., R.A.M.C.

CAPTAIN M. D. ConRoy, M.B., B.Ch., B.A.o., R.A.M.C.

Major I. M. M. BaGSHAW, M.B., Ch.B., M.R.C.G.P., D.obst.R.C.o.G., R.A.M.C:

MAJOR D. A. MOORE, M.B., B.S., R.A.M.C.

MAJOR J. P. SAUNDERS, M.B., B.S., M.R.C.S., L.R.C.P., R.A.M.C. 